\title{
Biochar application to temperate soils: effects on nutrient uptake and crop yield under field conditions
}

\author{
Jasmin Karer ${ }^{1}$, Bernhard Wimmer ${ }^{1}$, Franz Zehetner², Stefanie Kloss ${ }^{1,2}$ and Gerhard Soja ${ }^{1}$
}

${ }^{1}$ AIT Austrian Institute of Technology GmbH, Department Health and Environment, Konrad-Lorenz-Str. 24, 3430 Tulln, Austria

${ }^{2}$ University of Natural Resources and Life Sciences, Institute of Soil Research, Peter-Jordan-Str. 82, 1190 Wien, Austria

e-mail: jasmin.karer@gmx.at

\begin{abstract}
The benefits of biochar (BC) application to fertile, non-acidic soils in temperate climate regions might not always be as evident as for highly weathered tropical soils. The aim of our study was to investigate the effects of BC on soil characteristics, nutrient uptake and crop yield in field experiments on two temperate soils (Cambisol and Chernozem) in Austria. Maize and wheat (Cambisol), and barley and sunflower (Chernozem) were grown in successive vegetation periods following different $B C$ application rates $\left(0,24\right.$ and $72 \mathrm{t} \mathrm{ha}^{-1}$ at the start of the experiment), supplemented with identical mineral $\mathrm{N}$ supply in $33 \mathrm{~m}^{2}$ plots. $\mathrm{BC}$ treatments showed varying impacts on nutrient uptake of the investigated crops. The first growing season in the Chernozem region was affected by a prolonged drought period, which resulted in positive effects of BC on soil water-holding capacity $(\mathrm{WHC})$ and barley crop yield $(+10 \%)$ for the $72 \mathrm{t} \mathrm{ha}^{-1} \mathrm{BC}+\mathrm{N}$ treatment compared to a control with identical nutrient supply but without $\mathrm{BC}$. However, maize and wheat grain yield decreased by 46 and $70 \%$, respectively, after the highest $\mathrm{BC}$ application rate $\left(72 \mathrm{t} \mathrm{ha}^{-1}\right)$ in an additional treatment without supplementary $\mathrm{N}$-fertilisation. Still, even with high $\mathrm{BC}$ application rates we did not observe any adverse effects on crop yield and nutrient uptake, as long as the soil was supplied with sufficient $\mathrm{N}$ according to local agricultural practice.
\end{abstract}

Key words: Soil amendment, soil fertility, water-holding capacity, wheat, barley, maize, sunflower

$\begin{array}{ll}\text { Acronyms and abbreviations } \\ \text { BC } & \text { biochar } \\ \text { BD } & \text { bulk density } \\ \text { DM } & \text { dry mass } \\ \text { EC } & \text { electrical conductivity } \\ \text { CAL } & \text { calcium acetate lactate } \\ \text { CEC } & \text { cation exchange capacity } \\ \text { NPK } & \text { nitrogen (N), phosphorus (P), potassium (K) } \\ \text { NSP } & \text { nitrogen supplying potential } \\ \text { SOM } & \text { soil organic matter } \\ \text { PAW } & \text { plant available water } \\ \text { SD } & \text { standard deviation } \\ \text { WHC } & \text { water-holding capacity }\end{array}$




\section{Introduction}

The interest in biochar (BC) has extended from the effects on tropical soils to the potential of $\mathrm{BC}$ as a soil management strategy for global agriculture. After Terra Preta (Terra Preta de Indio, Portuguese for black earth) has been identified in the Amazon region in the $19^{\text {th }}$ century, it has been studied by naturalists, archaeologists and pedologists (da Costa et al. 2004). Terra Preta is classified as a fertile soil in an infertile surrounding, containing high concentrations of nutrients and stable soil organic matter (SOM) (Lehmann et al. 2003). The high amounts of SOM were caused by large inputs of domestic waste and black carbon that had formed due to natural and anthropogenic burning activities; therefore, up to 70 times more black carbon can be found in Terra Preta soils compared to the surrounding soils in the Amazon (Glaser et al. 2002, Novotny et al. 2009). These observations helped to create the hypothesis that the application of black carbon as pyrolysed biomass would increase the soil fertility of any agricultural soil. However, such a hypothesis is not self-evident and requires experimental confirmation.

Pyrolysis of biomass leads to the formation of the solid product BC that, upon application to the soil, may play an important role as a carbon sink and soil amendment. Among the potential benefits of $\mathrm{BC}$ for soil, the slow release of plant macronutrients contained in the $\mathrm{BC}$ is considered as a possibility to reduce the need for fertilisers in agriculture (Zheng et al. 2013a). Turning biomass into BC, oil and syngas by pyrolysis may even be carbon negative, if the syngas is used for energy purposes (Lehmann 2007, Goldberg 1985, Kuhlbusch and Crutzen 1995, Pramod et al. 2010, Ippolito et al. 2012).

In addition to $C$ sequestration in the soil, $B C$ comprises intrinsic properties that may make $B C$ suitable as a soil amendment. A number of studies on different $B C$ types and pyrolysis temperatures revealed that $B C$ may induce a liming effect in the soil with a concomitant increase in cation exchange capacity (CEC). Further, BC can also lead to increased water and nutrient holding capacity (Gaskin et al. 2008, Singh et al. 2010, Gaskin et al. 2010, Uzoma et al. 2011, Kloss et al. 2012, 2013).

The particular effects of $\mathrm{BC}$ application on soil and plant yield, however, are not only dependent on the quality of the $\mathrm{BC}$, but also on the specific soil characteristics (e.g. soil texture, SOM, pH). Most of the pot and field experiments that have been carried out were related to highly weathered, nutrient-poor tropical soils, as assorted in the reviews by Glaser et al. (2002), Blackwell et al. (2009) and Sohi et al. (2010). In the relevant studies, positive effects on both, soil and plants, were found, which might partly be attributed to a reduction of Al toxicity in the rhizosphere, as a result of the increase in pH (Kuka et al. 2013, Yang et al. 2013). However, the same effects may not be conferrable to other climatic regions with different soil types (Major et al. 2010) and, thus, require separate investigations. Studies that have been performed in temperate regions indicated that BC may cause only small, transient or even unwanted effects on soil and plant yield (Jones et al. 2012, Gaskin et al. 2010, Rajkovich et al. 2012, Kloss et al. 2013, Quilliam et al. 2012). Güereña et al. (2013) applied up to $30 \mathrm{t} \mathrm{ha}^{-1}$ BC in a North American temperate region, in a soil with sufficiently high native fertility. In their study, maize yield was within the current average yields of this region and hence, Güereña et al. (2013) suggest that specific soil productivity constraints have to be identified before BC application.

Asai et al. (2009) reported that the usage of BC without any further $\mathrm{N}$ fertiliser tended to decrease crop yield in soils with a low indigenous $\mathrm{N}$ supply. On the other hand, BC application in temperate regions may have other positive effects on the soil, which must not be disregarded. For example, Jeffery et al. (2011) concluded in a meta-analysis that BC application to medium and coarse textured soils increased soil WHC. The magnitude of this effect was found to be influenced by the respective soil characteristics. Atkinson et al. (2010) found that sandy soils were likely to have greater benefits from BC than clayey soils. They assumed that increased WHC of a soil (after $\mathrm{BC}$ application) was caused by a change in pore-size distribution and subsequently altered percolation patterns and flow paths. Liu et al. (2012) found synergetic positive effects of BC and compost in their field experiment in a sandy soil in Germany. Soil fertility and plant available water-holding capacity significantly increased after the compost-BC mixtures.

Detailed investigations of the effects of $\mathrm{BC}$ application on agricultural soils in temperate regions are crucial to better understand the potential of $\mathrm{BC}$ to increase soil fertility and to raise yields in soils outside of subtropical and tropical regions that are neither nutrient-deficient nor acidic. Therefore, this study had the objective to analyse the effects of a wood-derived BC on the crop yields in two representative agricultural soils in Central Europe over two years. Additionally, investigations of the effects on physico-chemical properties of the soils and on nutrient uptake of the crop plants should illuminate possible mechanisms for either positive or adverse yield effects of BC applications. 


\title{
Materials and methods
}

\author{
$\mathrm{BC}$ characterisation
}

Beech wood BC from S.C ROMCHAR S.R.L (Romania) was added at rates of $30 \mathrm{t} \mathrm{ha}^{-1}$ and $90 \mathrm{t} \mathrm{ha}^{-1}$ fresh mass, respectively, once at the start of the experiment. After correction for the $20 \%$ water content, the BC application rates amounted to 24 and $72 \mathrm{t} \mathrm{ha}^{-1}$ (Table 1). Representative samples from the $\mathrm{BC}$ used as additive at both field experiments were taken with $n=3$. The material was dried at $47^{\circ} \mathrm{C}$ until weight stability. The results of the $B C$ water content determinations were in close agreement with the specifications of the $\mathrm{BC}$ producer. The $\mathrm{BC}$ was a wood-based slow pyrolysis product $\left(550^{\circ} \mathrm{C}\right.$; $<2 \mathrm{~cm}$ ) with a pH of $9.0,80 \% \mathrm{C}, 1.6 \% \mathrm{H}, 0.4 \% \mathrm{~N}$, a H/C $\mathrm{C}_{\text {org }}$ ratio of 0.3 and a PAH content ( $\Sigma 16$ EPA PAH) of $9 \mathrm{mg} \mathrm{kg}^{-1}$. Concentrations of heavy metals amounted to (in $\mathrm{mg} \mathrm{kg}^{-1}$ ): $\mathrm{Cd}<0.2$, $\mathrm{Cr} 51, \mathrm{Cu} 16, \mathrm{~Pb} 2, \mathrm{Zn} 93, \mathrm{As}<0.8, \mathrm{Ni} 8, \mathrm{Tl}<0.2$ and $\mathrm{Hg}<0.07$.

\section{Study sites}

The two study sites are located in Lower Austria and Styria, Austria. The soil in Traismauer, Lower Austria (48 $19^{\prime} 52.6^{\prime \prime} \mathrm{N}, 15^{\circ} 44^{\prime} 20.5^{\prime \prime} \mathrm{E}$; parent material loess; $547 \mathrm{~mm}$ mean annual precipitation), was classified as a Chernozem with silt loam texture $\left(\mathrm{pH}\left(\mathrm{CaCl}_{2}\right): 7.4\right.$, CEC: $208.6 \mathrm{mmol}_{\mathrm{c}} \mathrm{kg}^{-1}, \mathrm{C} / \mathrm{N}$ ratio: 11.9 , carbonate: 15.8 w.-\%). The soil in Kaindorf, Styria $\left(47^{\circ} 13^{\prime} 46.0^{\prime \prime} \mathrm{N}, 15^{\circ} 50^{\prime} 40.6^{\prime \prime} \mathrm{E}\right.$; parent material tertiary sediments; $883 \mathrm{~mm}$ mean annual precipitation), was classified as Cambisol with clay loam texture $\left(\mathrm{pH}\left(\mathrm{CaCl}_{2}\right): 6.6, \mathrm{CEC}: 209.4 \mathrm{mmol}_{\mathrm{c}} \mathrm{kg}^{-1,} \mathrm{C} / \mathrm{N} \mathrm{ratio}\right.$ : 13.8, carbonate: 0.0 w.-\%). A detailed characterisation of the two soils was given in Kloss et al. (2013).

\section{Experimental setup in the field}

Plots had a circular shape because this geometry guaranteed the best ratio of large experimental area to low circumference. This lowered the risk of soil mixing at the outer plot zones and prevented the mixing in the inner (net) plot area. Each circular net plot (used for harvest analysis, soil and plant sampling) with a diameter of $3.5 \mathrm{~m}$ was positioned in the centre of a gross plot with $6.5 \mathrm{~m}$ diameter. The minimum distance between the outer borders of net plots was $6.5 \mathrm{~m}$; the minimum distance between the outer borders of gross plots was $0.5 \mathrm{~m}$. There were four different treatments with four replicates $(n=4)$, arranged as Latin Square. Nutrients $(N, P, K)$ were supplied according to standard agricultural practices in the respective region (Table 1 ). The treatments consisted of three different $\mathrm{BC}$ application rates $\left(0,24\right.$ and $\left.72 \mathrm{t} \mathrm{ha}^{-1}\right)$ with identical mineral $\mathrm{N}$ fertilisation and one additional treatment without $\mathrm{N}$ supplement but with a $\mathrm{BC}$ application rate of $72 \mathrm{t} \mathrm{ha}^{-1}$. The high $\mathrm{BC}$ application rate of $72 \mathrm{t}$ $\mathrm{ha}^{-1}$ was chosen to simulate carbon enrichments observed in historically amended, terra-preta-like soils (Downie et al. 2011). Among the four treatments we included one BC treatment without nitrogen addition because the, for a wood-based BC, relatively high $\mathrm{N}$ concentration of $0.4 \%$ would have meant an $\mathrm{N}$ addition of $288 \mathrm{~kg} \mathrm{ha}^{-1}$. This treatment should show if at least a part of this $\mathrm{N}$ pool could be of any use for the crops. BC was applied to the soil by dividing each plot in 8 sub-plots; each of these received the amount of BC corresponding to the area of this sub-plot. BC was moistened by hand with a watering-can $\left(1.5 \mathrm{I} \mathrm{m}^{-2}\right)$ immediately after application to avoid wind erosion. Incorporation into soil was achieved to a depth of $10 \mathrm{~cm}$ with a rotary hoe at low rotation speed. The experimental plots did not receive irrigation at any time, apart from the $\mathrm{BC}$ moistening at the initial application.

Table 1. BC application and fertilisation rates on the Cambisol and Chernozem in 2011 and 2012. N: Nitrogen; P: Phosphorus; K: Potassium. BC or fertiliser application rates are given for 2011 / 2012.

\begin{tabular}{|c|c|c|c|c|c|}
\hline & Treatment & $\mathrm{BC}\left(\mathrm{t} \mathrm{ha}^{-1}\right)$ & $\mathrm{N}\left(\mathrm{kg} \mathrm{ha}^{-1}\right)$ & $\mathrm{P}\left(\mathrm{kg} \mathrm{ha}^{-1}\right)$ & $\mathrm{K}\left(\mathrm{kg} \mathrm{ha}^{-1}\right)$ \\
\hline \multirow{4}{*}{$\begin{array}{l}\text { Cambisol } \\
\text { (Kaindorf) }\end{array}$} & fertiliser without BC (control) & $0 / 0$ & $150 / 120$ & $13 / 0$ & $46 / 0$ \\
\hline & $24 \mathrm{t} \mathrm{ha}^{-1} \mathrm{BC}+$ fertiliser & $24 / 0$ & $150 / 120$ & $13 / 0$ & $46 / 0$ \\
\hline & $72 \mathrm{t} \mathrm{ha}^{-1} \mathrm{BC}+$ fertiliser & $72 / 0$ & $150 / 120$ & $13 / 0$ & $46 / 0$ \\
\hline & $72 \mathrm{t} \mathrm{ha}^{-1} \mathrm{BC}$ without $\mathrm{N}$ supplement & $72 / 0$ & $0 / 0$ & $13 / 0$ & $46 / 0$ \\
\hline \multirow{4}{*}{$\begin{array}{l}\text { Chernozem } \\
\text { (Traismauer) }\end{array}$} & fertiliser without BC (control) & $0 / 0$ & $120 / 75$ & $26 / 31$ & $50 / 100$ \\
\hline & $24 \mathrm{tha}^{-1} \mathrm{BC}+$ fertiliser & $24 / 0$ & $120 / 75$ & $26 / 31$ & $50 / 100$ \\
\hline & $72 \mathrm{t} \mathrm{ha}^{-1} \mathrm{BC}+$ fertiliser & $72 / 0$ & $120 / 75$ & $26 / 31$ & $50 / 100$ \\
\hline & $72 \mathrm{t} \mathrm{ha}^{-1} \mathrm{BC}$ without $\mathrm{N}$ supplement & $72 / 0$ & $0 / 0$ & $26 / 31$ & $50 / 100$ \\
\hline
\end{tabular}




\section{Experimental management and sampling Kaindorf}

The addition and incorporation of BC into the Cambisol in Kaindorf took place on 31 March, 2011. The site was fertilised on 12 April, 2011 (nitrogen (N), phosphorus (P), potassium (K) = NPK; $\mathrm{N}_{2} \mathrm{P}_{2} \mathrm{O}_{5}: \mathrm{K}_{2} \mathrm{O}=20$ : 6: 11, Linzer Star, Borealis Linzer Agro Trade GmbH, Austria). Subsequently, maize (Zea mays L.) was sown on 25 April, 2011, followed by $\mathrm{N}$ fertilisation (Nitramoncal = 27\% ammonium nitrate) on 6 July, 2011. The maize was harvested on 28 September, 2011, followed by the sowing of winter wheat (Triticum aestivum L.) on 10 October, 2011 and fertilised with N (Nitramoncal = 27\% ammonium nitrate) on 12 March, 2012. The winter wheat was harvested on 17 July, 2012. Composite soil samples were taken on the days of harvest. From each plot we attained approximately 20 soil samples randomly from a depth of 0-17 cm and mixed.

\section{Traismauer}

Here, BC was incorporated on 16 March, 2011, followed by NPK ( $N: \mathrm{P}_{2} \mathrm{O}_{5}: \mathrm{K}_{2} \mathrm{O}=15: 15: 15$, Linzer Star) fertilisation on 11 April, 2011. Spring barley (Hordeum vulgare L.) was sown on 12 April, 2011 and fertilised (Nitramoncal) on 10 May, 2011. Spring barley was harvested on 21 July, 2011. Sunflower (Helianthus annuus L.) was sown on 20 April, 2012, and NPK (Nitramoncal = 27\% ammonium nitrate and DC 45 plus $\left(\mathrm{P}_{2} \mathrm{O}_{5}: \mathrm{K}_{2} \mathrm{O}=12: 20\right)$ ) added on 3 May, 2012.

Sunflower was harvested on 26 September, 2012. Composite soil samples (see above) were taken on the days of harvest.

\section{Climate and weather conditions}

In 2011, Kaindorf total annual precipitation sum was below average, with only $69.2 \%$ of the long-term mean $1971-$ 2000 (Fig. 1). In the first nine months of 2012, the precipitation was $83.4 \%$ of the long-term mean.

Traismauer experienced a more pronounced precipitation deficit in 2011 , with only $50.4 \%$ of the long-term mean 1971-2000 (Fig. 1). However, in the first nine months of 2012, precipitation was only slightly below average, reaching $93.1 \%$ of the 30 -year mean.

Kaindorf

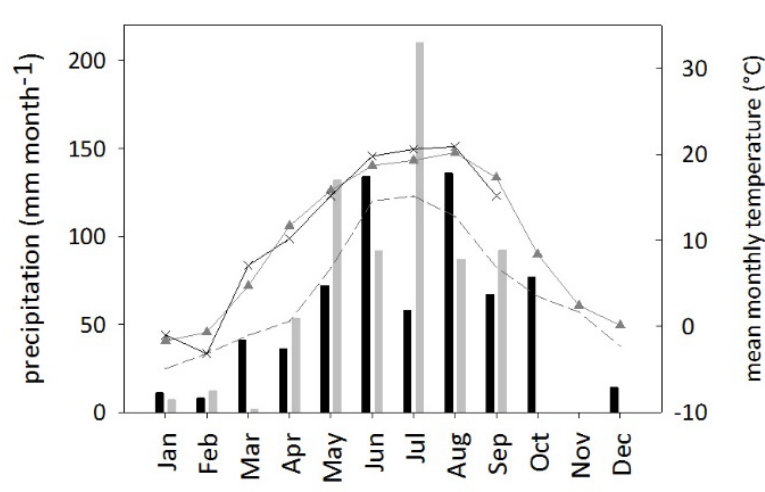

Traismauer

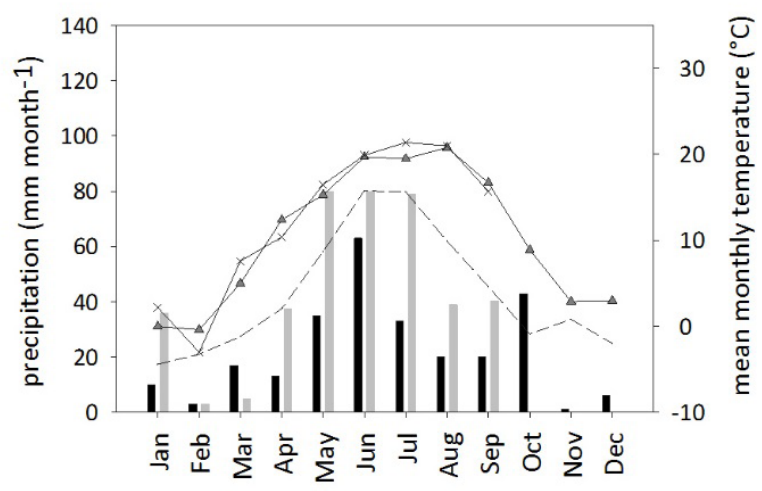

$$
\begin{aligned}
& 2011 \\
& 2012 \\
& --\quad 1971-2000 \text { (mean precipitation) } \\
& -\triangle \text { mean temperature } 2011 \\
& -\times \text { mean temperature } 2012
\end{aligned}
$$

Fig. 1. Monthly precipitation and temperature at the two study sites Kaindorf and Traismauer in 2011 and 2012 compared to the mean monthly precipitation (1971-2000). Weather data for 2012 are given until September, the month of the last harvest. 


\section{Analyses of soil samples}

The sampled soils were air-dried and sieved to $2 \mathrm{~mm}$. The $\mathrm{pH}$ was measured after brief shaking with $0.01 \mathrm{M} \mathrm{CaCl}$ solution (ratio 1:5), letting stand for $24 \mathrm{~h}$ and shaking again (inoLab pH Level 2P, Weilheim, Germany). The electrical conductivity (EC) was measured in a 1:10 (w:v) water extract after $24 \mathrm{~h}$ extraction (inoLab Cond Level 2 conductometer, Weilheim, Germany). Bulk density was determined according to the Austrian standard ÖNORM L 1051. Undisturbed soil cores were carefully taken by driving a metal cylinder with a volume of $200 \mathrm{~cm}^{3}$ into each soil plot $(n=4)$. The soil cores were dried at $105^{\circ} \mathrm{C}$ in the laboratory and the dry weight was determined after constant weight was reached (Blake and Hartge 1986). The cation exchange capacity (CEC) was measured according to ÖNorm L 1086 (2001), extracting $5 \mathrm{~g}$ of soil with $100 \mathrm{~mL} 0.1 \mathrm{M} \mathrm{BaCl}_{2}$ solution. The exchangeable cations (Ca, $\mathrm{Mg}, \mathrm{K}, \mathrm{Na}, \mathrm{Al}, \mathrm{Fe}, \mathrm{Mn}$ ) were measured by Atomic Absorption Spectroscopy (AAS; Perkin Elmer 2100; Überlingen, Germany); CEC was calculated as the sum of the exchangeable cations (in mmol $\mathrm{kg}^{-1}$ ). Further, nitrogen supplying potential (NSP) was determined by anaerobic incubation according to ÖNorm L 1091 (1999): to this end, $15 \mathrm{ml}$ of distilled water was added to $5 \mathrm{~g}$ of soil in each of three tubes. One tube was instantly deep-frozen to $-20{ }^{\circ} \mathrm{C}(\mathrm{A})$; the other two tubes were incubated for 7 days at $40^{\circ} \mathrm{C}(\mathrm{B})$. After the incubation period, the samples were shaken with $15 \mathrm{ml}$ of $4 \mathrm{M} \mathrm{KCl}$ solution for 30 minutes and filtered; $\mathrm{NH}_{4}^{+}-\mathrm{N}$ was determined photometrically (Agilent 8453, Waldbronn, Germany) using the Indophenol method 2 at $661 \mathrm{~nm}$. The NSP was calculated as the difference between $B$ and $A$. Phosphorus $\left(\mathrm{P}_{C A L}\right)$ and potassium $\left(\mathrm{K}_{\mathrm{CAL}}\right)$ were extracted with calcium-acetate-lactate $(\mathrm{CAL})$ according to ÖNorm L 1087 (2004). $P_{C A L}$ was measured with a photometer (Agilent 8453, Waldbronn, Germany) using the molybdenum-blue method originally published by Murphy and Riley (1962); $\mathrm{K}_{\mathrm{CAL}}$ was measured with AAS (Perkin Elmer 2100, Überlingen, Germany). Total carbon (C) and nitrogen (N) were determined by dry combustion, following the method of Tabatabai and Bremner (1991) and measured with an elemental analyser (CHNS-O EA 1108; Carlo Erba Instruments, Milano, Italy). Organic $\mathrm{C}\left(\mathrm{C}_{\text {org }}\right)$ was calculated as the difference of total $\mathrm{C}$ and carbonate content, which had been determined gas-volumetrically (Burt 2004). The fertilised soil and the soil-BC mixtures were packed into metal cylinders of a size of $100 \mathrm{~cm}^{3}$ to a desired bulk density (BD), in order to determine water holding capacity (WHC) and water retention characteristics ( $\mathrm{pF}$ curve). WHC was only defined for soil samples (after BC application) in 2011. For determination of the WHC, the soil cores were fully saturated and placed on a moist sand bed until the excess water had drained by gravity. The soil cores were weighed after equilibrium was reached. The water retention characteristics ( $\mathrm{pF}$ curve) of the samples were determined using the pressure chamber method (Austrian standard L 1063). The soil cores in the metal cylinders were saturated and drained at three pressure steps (6, 30 and $1500 \mathrm{kPa}$ ) until equilibrium was reached (Klute 1986). The water content of the samples was measured after each pressure step and after drying the samples at $105^{\circ} \mathrm{C}$ at the end of the procedure. Plant available water (PAW) was calculated as the difference between $\mathrm{pF} 1.8$ and 4.2 , in percentage.

\section{Analyses of plant samples}

For yield analysis, the net plots $\left(9.6 \mathrm{~m}^{2}\right.$ each) in the centre of each gross plot were harvested. The dried $\left(60{ }^{\circ} \mathrm{C}\right)$ harvest products of maize, barley, wheat and sunflower were separated in grain and straw, chaffed and milled before analysis. Macro- and micronutrients for grain and straw of all crops were analysed with inductively coupled plasma optical emission spectroscopy (ICP-OES; PerkinElmer OPTIMA 7300DV, Waltham, MA, USA) after full acid digestion $\left(\mathrm{HNO}_{3}: \mathrm{HClO}_{4}=20+4 \mathrm{~mL}\right.$; based on ÖNorm $\left.\mathrm{L} 1085,2009\right)$. $\mathrm{C}$ and $\mathrm{N}$ were analysed with an elemental analyser (EA1108, Carlo Erba Instruments). Nutrient uptake was calculated by multiplying grain and straw dry mass of the crops with the analysed macro- and micronutrient concentrations.

\section{Statistical analyses}

All statistical analyses were conducted with STATISTICA 8. Reported results are means \pm standard deviation (SD). Prior to the statistical analyses, all data were evaluated with the Dixon outlier test and outliers were eliminated before determining mean values and SD (Dixon 1950). Main effect ANOVA (analysis of variance) and Duncan's multiple range test were carried out in order to identify significant differences between the four varying treatments ( $p$ $<0.05)$. Analyses were conducted to a) identify whether BC can contribute the missing $\mathrm{N}$; for that hypothesis, the $72 \mathrm{t} \mathrm{ha}^{-1} \mathrm{BC}$ treatments with and without $\mathrm{N}$ application were analysed (compared by Duncan's multiple range test). The other investigation $b)$ concentrated on the effects of different $B C$ amounts $\left(0,24\right.$ and $72 t^{-1}$ ha ${ }^{-1}$ with identical mineral $\mathrm{N}$ supply. All four treatments were analysed in one run with a main effect ANOVA and subsequently, the means were tested with Duncan's multiple range test for significant differences. 


\section{Results \\ Effects on soil properties}

The effects of BC application on basic soil (fertility) parameters are shown in Table 2 and Table 3. In 2011, the Cambisol (Table 2) showed significantly increased $\mathrm{pH}$ and $\mathrm{EC}$ values upon $\mathrm{BC}$ addition; the differences between the different treatments disappeared one year later. All BC treatments showed significantly higher $\mathrm{C}_{\text {org }}$ and $\mathrm{C} / \mathrm{N}$ and lower BD values for both years. CEC and NSP were not significantly affected by BC application. Higher BC application rates showed significant increases of $\mathrm{K}_{\mathrm{CAL}}$ in both years and of $\mathrm{P}_{\mathrm{CAL}}$ in the first but not in the second year.

Unlike in the Cambisol, the pH of the Chernozem (Table 3) did not increase after BC application and even decreased significantly after the $\mathrm{BC} 72 \mathrm{t} \mathrm{ha}^{-1}$ treatment with $\mathrm{N}$ supplement in the first year. Concomitantly, CEC was not affected by $B C$ application. BD was unaffected in the first year, but had significantly lower values after both BC $72 \mathrm{t} \mathrm{ha}^{-1}$ treatments in 2012, the second year of the study. Only the $72 \mathrm{t}$ ha ${ }^{-1} \mathrm{BC}$ treatment $+\mathrm{N}$ supplement induced a significant increase of EC. The $72 \mathrm{tha}^{-1} \mathrm{BC}$ applications caused significantly higher $\mathrm{C}_{\text {org }}$ and $\mathrm{C} / \mathrm{N}$ values in both years. In the first year, $72 \mathrm{t} \mathrm{ha}^{-1} \mathrm{BC}$ without $\mathrm{N}$ supplement evoked a significantly lower NSP than with $\mathrm{N}$ supply, which then evened out in the second year. $\mathrm{K}_{C A L}$ and $\mathrm{P}_{\text {CAL }}$ were both significantly higher after $72 \mathrm{tha}^{-1} \mathrm{BC}+\mathrm{N}$ supplement in the first year.

\section{Effects on soil water}

In the Cambisol, BC application caused significant increases in WHC (Table 2). The pF curve (Fig. 2) shows that both $\mathrm{BC} 72 \mathrm{t} \mathrm{ha}^{-1}$ treatments had significantly higher volumetric water contents at pF 0 . Similarly, at pF 1.8 these two treatments had the highest volumetric contents. There was no significance for the water contents at pF 2.5 while at pF 4.2 the $B C 24 \mathrm{t} \mathrm{ha}^{-1}+\mathrm{N}$ application showed the lowest volumetric water content within the $\mathrm{BC}$ treated soils. PAW significantly increased after $72 \mathrm{t} \mathrm{ha}^{-1} \mathrm{BC}$ amendment, with and without $\mathrm{N}$ fertilisation (Fig. 2). In the Chernozem soil, BC showed similar trends in WHC characteristic than in the Cambisol but these were not statistically significant (Table 3). The pF curve (Fig. 2) showed, similar to the Cambisol, that both BC $72 \mathrm{t}^{-1}{ }^{-1}$ treated plots had significantly higher volumetric water contents at $\mathrm{pF} 0$ and $\mathrm{pF}$ 1.8. There was no significance in the water contents at pF 2.5 and 4.2. PAW increased through BC application, albeit not statistically significant (Fig. 2).

\section{Effects on crop yield}

If supplementary $\mathrm{N}$ application was absent, all crops showed significant yield decreases after $72 \mathrm{t}$ ha-1 $\mathrm{BC}$ amendment (Fig. 3). In the first year of the experiment, in 2011, maize total aboveground biomass yield decreased by $37 \%$ (on the Cambisol), if $\mathrm{N}$ application was missing at the $72 \mathrm{t} \mathrm{ha}^{-1} \mathrm{BC}$ treatment. In the second year, 2012, biomass yield of winter wheat decreased even more, by $71 \%$, comparing the above-mentioned treatments. However, varying $B C$ amendments $\left(0,24\right.$ and $\left.72 \mathrm{t} \mathrm{ha}^{-1}\right)$ with identical mineral $\mathrm{N}$ supply did not cause significant differences on the total biomass yields of maize and wheat.

The individual yield analyses of grain and straw of maize and wheat showed varying results: Maize grain decreased by $45 \%$ if $\mathrm{N}$ application was not supplemented at the high $\mathrm{BC}$ application rate, while maize straw was not significantly affected. Grain and straw yield of winter wheat, however, declined to the same degree by $71 \%$ at $72 \mathrm{t}$ ha- 1 without $\mathrm{N}$ application. The varying $\mathrm{BC}$ applications $\left(0,24\right.$ and $\left.72 \mathrm{t} \mathrm{ha}^{-1}\right)$ with identical $\mathrm{N}$ supply did not result in significant yield differences in the grain and straw yields of neither maize nor wheat.

In the Chernozem soil, the study of $\mathrm{N}$ deficiency after $72 \mathrm{t} \mathrm{ha}^{-1} \mathrm{BC}$ application without $\mathrm{N}$ supplement revealed a lower decrease than in the Cambisol: barley (2011) and sunflower (2012) total above-ground biomass yields were reduced by $23 \%$ and $14 \%$, respectively. For barley, the grain yield decrease was more distinct than the straw yield whereas in sunflower the decrease in straw yield was more apparent than in grain yield if $\mathrm{N}$ supplement was missing

At sufficient $\mathrm{N}$ supply, barley grain and straw as well as sunflower straw were not significantly affected after varying $\mathrm{BC}$ treatment $\left(0,24\right.$ and $\left.72 \mathrm{t} \mathrm{ha}^{-1}\right)$ with identical mineral $\mathrm{N}$ application rates. Sunflower, however, showed slightly $(+10 \%)$ higher grain yields after $24 \mathrm{t} \mathrm{ha}^{-1} \mathrm{BC}$ amendment but not for total aboveground dry matter. 
Table 2. Effects of BC on soil properties ( $n=4$; mean value) of the Cambisol for 2011 and 2012. Soils were sampled immediately after crop harvest. Different letters in lines for each parameter indicate significant differences at $p<0.05$ (Duncan's multiple range test). EC: Electrical conductivity; BD: Bulk density; CEC: Cation exchange capacity; NSP: Nitrogen Supplying Potential; KCAL/ PCAL: CAL-extractable potassium/phosphorus; WHC: Water holding capacity; PAW: plant available water.

\begin{tabular}{|c|c|c|c|c|c|c|c|c|}
\hline \multirow[t]{2}{*}{ Soil parameter } & \multicolumn{2}{|c|}{$\begin{array}{l}\text { BC } 0 \text { t ha }^{-1} / \\
\text { N } 150 \mathrm{~kg} \mathrm{ha}^{-1}\end{array}$} & \multicolumn{2}{|c|}{$\begin{array}{l}\text { BC } 24 \mathrm{t} \mathrm{ha}^{-1} / \\
\text { N } 150 \mathrm{~kg} \mathrm{ha}^{-1}\end{array}$} & \multicolumn{2}{|c|}{$\begin{array}{l}\text { BC } 72 \text { t ha }^{-1} / \\
\text { N } 150 \text { kg ha }^{-1}\end{array}$} & \multicolumn{2}{|c|}{$\begin{array}{c}\text { BC } 72 \mathrm{t} \mathrm{ha}^{-1} / \\
\text { N } 0 \text { kg ha-1 }\end{array}$} \\
\hline & 2011 & 2012 & 2011 & 2012 & 2011 & 2012 & 2011 & 2012 \\
\hline $\mathrm{pH}$ & $6.30^{a}$ & $6.71^{\mathrm{a}}$ & $6.50^{\mathrm{b}}$ & $6.69^{a}$ & $6.65^{c}$ & $6.75^{\mathrm{a}}$ & $6.65^{c}$ & $6.71^{a}$ \\
\hline $\mathrm{EC}\left(\mu \mathrm{S} \mathrm{cm} \mathrm{cm}^{-1}\right)$ & $64.3^{\mathrm{a}}$ & $83^{\mathrm{a}}$ & $67.7^{\mathrm{a}}$ & $97^{a}$ & $83.3^{b}$ & $100^{\mathrm{a}}$ & $89.1^{\mathrm{b}}$ & $94^{\mathrm{a}}$ \\
\hline $\mathrm{BD}\left(\mathrm{g} \mathrm{cm}^{-3}\right)$ & $1.26^{c}$ & $1.36^{\mathrm{b}}$ & $1.15^{\mathrm{b}}$ & $1.26^{\mathrm{a}}$ & $1.09^{\mathrm{ab}}$ & $1.17^{\mathrm{a}}$ & $1.07^{a}$ & $1.18^{\mathrm{a}}$ \\
\hline $\mathrm{CEC}\left(\mathrm{mmol}_{\mathrm{c}} \mathrm{kg}^{-1}\right)$ & $187^{\mathrm{a}}$ & $204^{a}$ & $195^{\mathrm{ab}}$ & $211^{\mathrm{ab}}$ & $197^{\mathrm{ab}}$ & $209^{a b}$ & $204^{b}$ & $214^{b}$ \\
\hline $\mathrm{C} / \mathrm{N}$ ratio & $17.6^{\mathrm{a}}$ & $12.74^{a}$ & $30.5^{b}$ & $24.35^{b}$ & $56.0^{d}$ & $25.07^{b}$ & $48.8^{c}$ & $20.84^{b}$ \\
\hline $\mathrm{C}_{\text {org }}(\%)$ & $2.5^{\mathrm{a}}$ & $2.40^{\mathrm{a}}$ & $4.8^{b}$ & $4.58^{\mathrm{bc}}$ & $8.8^{c}$ & $5.36^{c}$ & $7.9^{c}$ & $3.85^{b}$ \\
\hline $\mathrm{NSP}\left(\mu \mathrm{g} \mathrm{g}^{-1} \mathrm{~d}^{-1}\right)$ & $16.6^{a}$ & $16.0^{\mathrm{a}}$ & $16.5^{\mathrm{a}}$ & $16.5^{\mathrm{a}}$ & $15.3^{a}$ & $16.7^{\mathrm{a}}$ & $16.5^{a}$ & $16.9^{a}$ \\
\hline $\mathrm{K}_{\mathrm{CAL}}\left(\mathrm{mg} \mathrm{kg}^{-1}\right)$ & $171^{\mathrm{a}}$ & $146^{a}$ & $185^{\mathrm{ab}}$ & $188^{\mathrm{bc}}$ & $213^{b c}$ & $175^{\mathrm{ab}}$ & $246^{c}$ & $209^{c}$ \\
\hline$P_{\text {CAL }}\left(\mathrm{mg} \mathrm{kg}^{-1}\right)$ & $70.3^{a}$ & $80^{\mathrm{a}}$ & $69.9^{a}$ & $80^{a}$ & $90^{b}$ & $91^{\mathrm{a}}$ & $70.3^{\mathrm{a}}$ & $77^{\mathrm{a}}$ \\
\hline WHC (\%) & $47.6^{a}$ & & $51.7^{\mathrm{b}}$ & & $57.44^{c}$ & & $57.8^{c}$ & \\
\hline PAW (\%) & $16.5^{\mathrm{a}}$ & & $18.2^{\mathrm{ab}}$ & & $19.6^{b}$ & & $20.1^{b}$ & \\
\hline
\end{tabular}

Table 3. Effects of BC on soil properties ( $n=4$; mean value) of the Chernozem for 2011 and 2012. Soils were sampled immediately after crop harvest. Different letters in lines for each parameter indicate significant differences at $p<0.05$ (Duncan's multiple range test). EC: Electrical conductivity; BD: Bulk density; CEC: Cation exchange capacity; NSP: Nitrogen Supplying Potential; KCAL/ PCAL: CAL-extractable potassium/phosphorus; WHC: Water holding capacity; PAW: plant available water.

\begin{tabular}{|c|c|c|c|c|c|c|c|c|}
\hline \multirow[t]{2}{*}{ Soil parameter } & \multicolumn{2}{|c|}{$\begin{array}{l}\text { BC } 0 \text { t ha-1/ } \\
\text { N } 150 \mathrm{~kg} \mathrm{ha}^{-1}\end{array}$} & \multicolumn{2}{|c|}{$\begin{array}{l}\text { BC } 24 \text { t ha-1/ }^{-1} \\
\text { N } 150 \mathrm{~kg} \mathrm{ha}^{-1}\end{array}$} & \multicolumn{2}{|c|}{$\begin{array}{l}\text { BC } 72 \text { t ha-1/ }^{-1} \\
\text { N } 150 \mathrm{~kg} \mathrm{ha}^{-1}\end{array}$} & \multicolumn{2}{|c|}{$\begin{array}{c}\text { BC } 72 \text { t ha }^{-1} / \\
\text { N } 0 \text { kg ha-1 }\end{array}$} \\
\hline & 2011 & 2012 & 2011 & 2012 & 2011 & 2012 & 2011 & 2012 \\
\hline $\mathrm{pH}$ & $7.40^{\mathrm{a}}$ & $7.20^{\mathrm{a}}$ & $7.40^{\mathrm{a}}$ & $7.18^{\mathrm{a}}$ & $7.30^{\mathrm{b}}$ & $7.19^{\mathrm{a}}$ & $7.40^{\mathrm{a}}$ & $7.22^{\mathrm{a}}$ \\
\hline $\mathrm{EC}\left(\mu \mathrm{S} \mathrm{cm} \mathrm{cm}^{-1}\right)$ & $123^{a}$ & $128.8^{\mathrm{ab}}$ & $128^{a}$ & $134.1^{b}$ & $142^{b}$ & $140.7^{b}$ & $122^{a}$ & $121.6^{a}$ \\
\hline $\mathrm{BD}\left(\mathrm{g} \mathrm{cm}^{-3}\right)$ & $1.29^{\mathrm{a}}$ & $1.44^{b}$ & $1.30^{\mathrm{a}}$ & $1.35^{\mathrm{b}}$ & $1.19^{\mathrm{a}}$ & $1.16^{\mathrm{a}}$ & $1.21^{\mathrm{a}}$ & $1.16^{\mathrm{a}}$ \\
\hline $\mathrm{CEC}\left(\mathrm{mmol}_{\mathrm{c}} \mathrm{kg}^{-1}\right)$ & $201^{a}$ & $198^{a}$ & $202^{a}$ & $210^{\mathrm{a}}$ & $209^{a}$ & $209^{a}$ & $204^{a}$ & $208^{a}$ \\
\hline $\mathrm{C} / \mathrm{N}$ ratio & $14.6^{\mathrm{a}}$ & $11.9^{a}$ & $27.0^{\mathrm{a}}$ & $18.7^{b}$ & $48.3^{b}$ & $33.5^{c}$ & $50.3^{b}$ & $32.7^{c}$ \\
\hline $\mathrm{C}_{\text {org }}(\%)$ & $1.72^{\mathrm{a}}$ & $1.87^{\mathrm{a}}$ & $3.28^{\mathrm{b}}$ & $2.97^{\mathrm{a}}$ & $4.91^{c}$ & $6.54^{\mathrm{b}}$ & $6.56^{d}$ & $5.89^{b}$ \\
\hline $\mathrm{NSP}\left(\mu \mathrm{g} \mathrm{g}^{-1} \mathrm{~d}^{-1}\right)$ & $13.9^{b}$ & $8.03^{a}$ & $14.3^{\mathrm{b}}$ & $9.44^{\mathrm{a}}$ & $14.4^{b}$ & $9.15^{\mathrm{a}}$ & $10.6^{a}$ & $8.07^{a}$ \\
\hline $\mathrm{K}_{\mathrm{CAL}}\left(\mathrm{mg} \mathrm{kg}^{-1}\right)$ & $247^{a}$ & $233^{\mathrm{ab}}$ & $277^{a}$ & $278^{b}$ & $396^{\mathrm{b}}$ & $243^{b}$ & $265^{a}$ & $177^{\mathrm{a}}$ \\
\hline$P_{\text {CAL }}\left(\mathrm{mg} \mathrm{kg}^{-1}\right)$ & $77^{\mathrm{ab}}$ & $82^{c}$ & $59^{a}$ & $74^{\mathrm{bc}}$ & $94^{b}$ & $71^{b}$ & $55^{\mathrm{a}}$ & $61^{\mathrm{a}}$ \\
\hline WHC (\%) & $35.5^{a}$ & & $43.3^{a}$ & & $41.2^{\mathrm{a}}$ & & $49.4^{a}$ & \\
\hline PAW (\%) & $18.6^{\mathrm{a}}$ & & $20.8^{a}$ & & $24.6^{a}$ & & $26.4^{\mathrm{a}}$ & \\
\hline
\end{tabular}



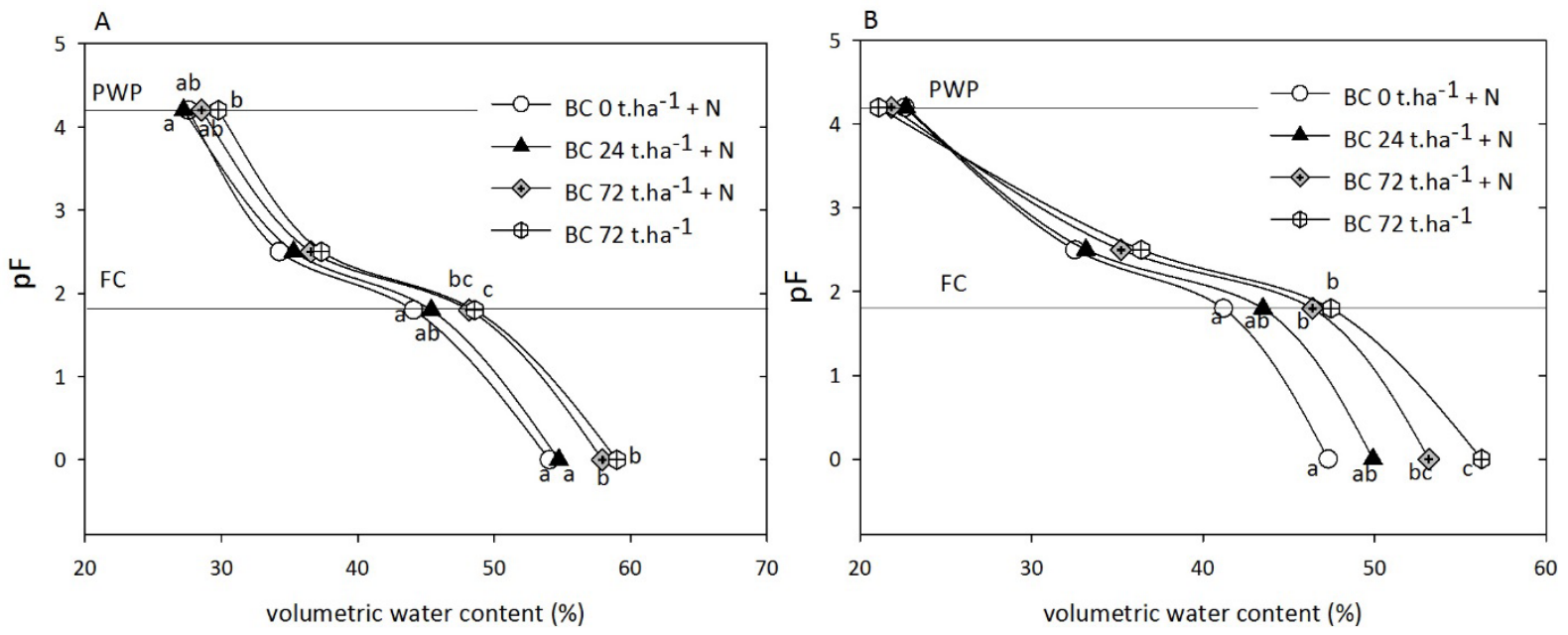

Fig. 2. pF curves of the Cambisol $(A)$ and the Chernozem (B) $(n=4)$. Volumetric water contents were determined at $p F 0,1.8,2.5$ and 4.2. Different letters indicate significant differences at $p<0.05$ (Duncan's multiple range test). PWP: Permanent wilting point; FC: Field capacity.

\section{Effects on nutrient uptake}

The effects of BC application on plant nutrient uptake (N, P, K, Ca, Al, B, Cu, Fe, Mn, Mo, Na, Zn) are shown in Table $4 \mathrm{a}-4 \mathrm{~d}$. For the Cambisol, $72 \mathrm{t} \mathrm{ha}{ }^{-1} \mathrm{BC}$ without $\mathrm{N}$ supplement caused a significantly lower $\mathrm{N}$ uptake for maize (44\% lower than in the treatment with the same BC rate including N supply; Table 4a). All other treatments with the same $\mathrm{N}$ supply but varying $\mathrm{BC}$ addition showed an $\mathrm{N}$ uptake in the range of $111-131 \mathrm{~kg} \mathrm{ha}^{-1}$. Comparable results were observed in the second crop, winter wheat, in 2012 (Table 4b). The variable BC application rates did not affect the total uptake of nearly all macro- and micronutrients analysed in this study, the same $\mathrm{N}$ supply provided. Only the $\mathrm{N}$ deficiency treatment occasionally showed uptake rates that were higher than the respective biomass yield reduction in comparison to the same $\mathrm{BC}$ treatment including $\mathrm{N}$. This was the case for some trace elements (especially $\mathrm{Na}, \mathrm{Zn}, \mathrm{Mn}, \mathrm{Fe}, \mathrm{Al}$ ) as well as $\mathrm{Ca}$ and $\mathrm{K}$.

On the Chernozem soil we also observed a significant decrease of $\mathrm{N}$ uptake for the $72 \mathrm{t} \mathrm{ha}^{-1}$ treatment without additional $\mathrm{N}$ supplement for both barley (2011) and sunflower (2012) (Table 4c, 4d). This treatment also showed significantly lower uptake of $\mathrm{P}$ and $\mathrm{K}$ compared to the same $\mathrm{BC}$ addition but with $\mathrm{N}$ application. There were no significant changes in Al and Fe uptake after any BC treatment. At the same time, Mo uptake significantly decreased in both $72 \mathrm{t} \mathrm{ha}^{-1} \mathrm{BC}$ treatments for barley (Table 4c) while it increased in the $72 \mathrm{t} \mathrm{ha}^{-1} \mathrm{BC}$ treatment without $\mathrm{N}$ supplement for sunflower (Table 4d).

Table 4a. Effects of BC on nutrient uptake (grain + straw) by maize in 2011, cultivated on Cambisol. Values are means \pm SD; numbers in lines followed by different letters are significantly different at $p<0.05$ (Duncan's multiple range test).

\begin{tabular}{|c|c|c|c|c|c|c|c|c|c|c|c|c|}
\hline \multirow{2}{*}{$\begin{array}{l}\text { Element } \\
\mathrm{N}\left(\mathrm{kg} \mathrm{ha}^{-1}\right)\end{array}$} & \multicolumn{3}{|c|}{$\begin{array}{c}\text { BC } 0 \mathrm{t} \mathrm{ha}^{-1} / \\
\text { N } 150 \mathrm{~kg} \mathrm{ha}^{-1}\end{array}$} & \multicolumn{3}{|c|}{$\begin{array}{l}\text { BC } 24 \mathrm{t} \mathrm{ha}^{-1} / \\
\text { N } 150 \mathrm{~kg} \mathrm{ha}^{-1}\end{array}$} & \multicolumn{3}{|c|}{$\begin{array}{l}\text { BC } 72 \mathrm{t} \mathrm{ha}^{-1} / \\
\text { N } 150 \mathrm{~kg} \mathrm{ha}^{-1}\end{array}$} & \multicolumn{3}{|c|}{$\begin{array}{c}\text { BC } 72 \mathrm{t} \mathrm{ha}^{-1} / \\
\text { N } 0 \mathrm{~kg} \mathrm{ha}^{-1}\end{array}$} \\
\hline & 111 & \pm & $29^{b}$ & 131 & \pm & $32^{b}$ & 116 & \pm & $17^{b}$ & 65 & \pm & $13^{a}$ \\
\hline$P\left(\mathrm{~kg} \mathrm{ha}^{-1}\right)$ & 32.2 & \pm & $0.5^{\mathrm{a}}$ & 31.4 & \pm & $6.9^{a}$ & 29.4 & \pm & $2.6^{a}$ & 24.4 & \pm & $2.9^{a}$ \\
\hline $\mathrm{K}\left(\mathrm{kg} \mathrm{ha}^{-1}\right)$ & 11.3 & \pm & $2.7^{\mathrm{ab}}$ & 15.7 & \pm & $4.2^{b}$ & 13.3 & \pm & $2.8^{\mathrm{ab}}$ & 9.0 & \pm & $1.8^{\mathrm{a}}$ \\
\hline $\mathrm{Ca}\left(\mathrm{kg} \mathrm{ha} \mathrm{a}^{-1}\right)$ & 23.3 & \pm & $6.2^{\mathrm{a}}$ & 26.8 & \pm & $8.0^{\mathrm{a}}$ & 21.5 & \pm & $5.2^{\mathrm{a}}$ & 15.1 & \pm & $3.2^{\mathrm{a}}$ \\
\hline $\mathrm{Mg}\left(\mathrm{kg} \mathrm{ha} \mathrm{f}^{-1}\right)$ & 19.9 & \pm & $5.2^{\mathrm{ab}}$ & 22.8 & \pm & $5.7^{\mathrm{b}}$ & 19.2 & \pm & $3.0^{\mathrm{ab}}$ & 15.5 & \pm & $2.2^{\mathrm{a}}$ \\
\hline $\mathrm{Al}\left(\mathrm{kg} \mathrm{ha}^{-1}\right)$ & 2.65 & \pm & $1.33^{\mathrm{a}}$ & 3.17 & \pm & $0.61^{\mathrm{a}}$ & 1.83 & \pm & $0.46^{a}$ & 3.09 & \pm & $0.69^{a}$ \\
\hline $\mathrm{B}\left(\mathrm{g} \mathrm{ha}^{-1}\right)$ & 39.7 & \pm & $6.8^{a}$ & 51.9 & \pm & $4.1^{b}$ & 38.9 & \pm & $7.7^{\mathrm{a}}$ & 29.8 & \pm & $0.8^{a}$ \\
\hline $\mathrm{Cu}\left(\mathrm{g} \mathrm{ha}^{-1}\right)$ & 34.1 & \pm & $13.8^{\mathrm{a}}$ & 39.7 & \pm & $10.5^{\mathrm{a}}$ & 35.1 & \pm & $9.2^{\mathrm{a}}$ & 19.3 & \pm & $3.7^{\mathrm{a}}$ \\
\hline $\mathrm{Fe}\left(\mathrm{g} \mathrm{ha}^{-1}\right)$ & 1778 & \pm & $1026^{a}$ & 1968 & \pm & $400^{a}$ & 1185 & \pm & $267^{a}$ & 1834 & \pm & $429^{a}$ \\
\hline $\mathrm{Mn}\left(\mathrm{g} \mathrm{ha}^{-1}\right)$ & 265 & \pm & $41^{b}$ & 287 & \pm & $14^{b}$ & 195 & \pm & $20^{\mathrm{a}}$ & 266 & \pm & $45^{b}$ \\
\hline Mo (g ha $\left.{ }^{-1}\right)$ & 3.34 & \pm & $1.37^{\mathrm{a}}$ & 3.69 & \pm & $0.22^{a}$ & 4.02 & \pm & $0.48^{a}$ & 3.38 & \pm & $1.00^{\mathrm{a}}$ \\
\hline $\mathrm{Na}\left(\mathrm{g} \mathrm{ha}^{-1}\right)$ & 91 & \pm & $30^{\mathrm{a}}$ & 112 & \pm & $26^{\mathrm{a}}$ & 82 & \pm & $18^{\mathrm{a}}$ & 96 & \pm & $11^{\mathrm{a}}$ \\
\hline $\mathrm{Zn}\left(\mathrm{g} \mathrm{ha}^{-1}\right)$ & 462 & \pm & $4^{a}$ & 485 & \pm & $74^{a}$ & 413 & \pm & $45^{a}$ & 430 & \pm & $127^{a}$ \\
\hline
\end{tabular}


Table 4b. Effects of BC on nutrient uptake (grain + straw) by winter wheat in 2012 , cultivated on Cambisol. Values are means $\pm \mathrm{S} \pm$ SD; numbers in lines followed by different letters are significantly different at $p<0.05$ (Duncan's multiple range test).

\begin{tabular}{|c|c|c|c|c|c|c|c|c|c|c|c|c|}
\hline \multirow{2}{*}{$\begin{array}{l}\text { Element } \\
\mathrm{N}\left(\mathrm{kg} \mathrm{ha}^{-1}\right)\end{array}$} & \multicolumn{3}{|c|}{$\begin{array}{l}\text { BC } 0 \mathrm{t} \mathrm{ha}^{-1} / \\
\text { N } 75 \mathrm{~kg} \mathrm{ha}^{-1}\end{array}$} & \multicolumn{3}{|c|}{$\begin{array}{l}\text { BC } 24 \mathrm{t} \mathrm{ha}^{-1} / \\
\text { N } 75 \mathrm{~kg} \mathrm{ha}^{-1}\end{array}$} & \multicolumn{3}{|c|}{$\begin{array}{l}\text { BC } 72 \text { t ha }^{-1} / \\
\text { N } 75 \mathrm{~kg} \mathrm{ha}^{-1}\end{array}$} & \multicolumn{3}{|c|}{$\begin{array}{l}\text { BC } 72 \mathrm{t} \mathrm{ha}^{-1} / \\
\text { N } 0 \mathrm{~kg} \mathrm{ha}^{-1}\end{array}$} \\
\hline & 160 & \pm & $40^{b}$ & 159 & \pm & $41^{b}$ & 159 & \pm & $25^{b}$ & 55 & \pm & $21^{\mathrm{a}}$ \\
\hline$P\left(\mathrm{~kg} \mathrm{ha}^{-1}\right)$ & 25.6 & \pm & $5.1^{b}$ & 27.2 & \pm & $5.5^{b}$ & 26.9 & \pm & $2.5^{b}$ & 14.7 & \pm & $6.4^{\mathrm{a}}$ \\
\hline $\mathrm{K}\left(\mathrm{kg} \mathrm{ha}^{-1}\right)$ & 66 & \pm & $38^{a}$ & 92 & \pm & $41^{\mathrm{a}}$ & 68 & \pm & $5^{a}$ & 42 & \pm & $17^{a}$ \\
\hline $\mathrm{Ca}\left(\mathrm{kg} \mathrm{ha}^{-1}\right)$ & 12.0 & \pm & $5.5^{\mathrm{a}}$ & 14.8 & \pm & $6.4^{\mathrm{a}}$ & 11.8 & \pm & $2.1^{\mathrm{a}}$ & 12.2 & \pm & $7.3^{\mathrm{a}}$ \\
\hline $\mathrm{Mg}\left(\mathrm{kg} \mathrm{ha}^{-1}\right)$ & 11.9 & \pm & $2.6^{\mathrm{ab}}$ & 13.7 & \pm & $3.7^{\mathrm{b}}$ & 12.4 & \pm & $1.0^{\mathrm{ab}}$ & 7.9 & \pm & $3.5^{\mathrm{a}}$ \\
\hline Al (kg ha-1) & 0.70 & \pm & $0.37^{a}$ & 0.80 & \pm & $0.57^{a}$ & 0.48 & \pm & $0.27^{a}$ & 3.49 & \pm & $2.56^{b}$ \\
\hline $\mathrm{B}\left(\mathrm{g} \mathrm{ha}^{-1}\right)$ & 11.0 & \pm & $3.0^{\mathrm{ab}}$ & 13.2 & \pm & $1.2^{\mathrm{b}}$ & 10.9 & \pm & $0.7^{\mathrm{ab}}$ & 7.5 & \pm & $3.1^{\mathrm{a}}$ \\
\hline $\mathrm{Cu}\left(\mathrm{g} \mathrm{ha}^{-1}\right)$ & 36.7 & \pm & $7.7^{\mathrm{b}}$ & 44.4 & \pm & $1.5^{b}$ & 37.3 & \pm & $4.5^{b}$ & 17.8 & \pm & $6.9^{a}$ \\
\hline $\mathrm{Fe}\left(\mathrm{g} \mathrm{ha}^{-1}\right)$ & 699 & \pm & $226^{a}$ & 850 & \pm & $384^{a}$ & 656 & \pm & $168^{\mathrm{a}}$ & 1432 & \pm & $806^{a}$ \\
\hline Mn (g ha-1) & 355 & \pm & $146^{\mathrm{ab}}$ & 495 & \pm & $323^{b}$ & 360 & \pm & $141^{\mathrm{ab}}$ & 256 & \pm & $165^{\mathrm{a}}$ \\
\hline Mo (g ha-1) & 5.62 & \pm & $0.02^{\mathrm{a}}$ & 6.21 & \pm & $0.53^{\mathrm{a}}$ & 7.93 & \pm & $1.98^{\mathrm{a}}$ & 4.46 & \pm & $2.45^{\mathrm{a}}$ \\
\hline $\mathrm{Na}\left(\mathrm{g} \mathrm{ha}^{-1}\right)$ & 72.8 & \pm & $18.9^{a}$ & 88.3 & \pm & $40.2^{\mathrm{a}}$ & 61.4 & \pm & $6.0^{\mathrm{a}}$ & 158.2 & \pm & $104^{\mathrm{a}}$ \\
\hline Zn $\left(\mathrm{g} \mathrm{ha}^{-1}\right)$ & 293 & \pm & $62^{\mathrm{b}}$ & 354 & \pm & $24^{b}$ & 320 & \pm & $64^{b}$ & 162 & \pm & $68^{a}$ \\
\hline
\end{tabular}

Table 4c. Effects of BC on nutrient uptake (grain + straw) by barley in 2011, cultivated on Chernozem. Values are means \pm SD; numbers in lines followed by different letters are significantly different at $p<0.05$ (Duncan's multiple range test).

\begin{tabular}{|c|c|c|c|c|c|c|c|c|c|c|c|c|}
\hline \multirow{2}{*}{$\begin{array}{l}\text { Element } \\
\mathrm{N}\left(\mathrm{kg} \mathrm{ha}^{-1}\right)\end{array}$} & \multicolumn{3}{|c|}{$\begin{array}{l}\text { BC } 0 \mathrm{t} \mathrm{ha}^{-1} / \\
\text { N } 120 \mathrm{~kg} \mathrm{ha}^{-1}\end{array}$} & \multicolumn{3}{|c|}{$\begin{array}{l}\text { BC } 24 \text { t ha-1/ }^{-1} \\
\text { N } 120 \mathrm{~kg} \mathrm{ha}^{-1}\end{array}$} & \multicolumn{3}{|c|}{$\begin{array}{l}\text { BC } 72 \text { t ha }^{-1} / \\
\text { N } 120 \mathrm{~kg} \mathrm{ha}^{-1}\end{array}$} & \multicolumn{3}{|c|}{$\begin{array}{l}\text { BC } 72 \text { t ha-1/ }^{-1} \\
\text { N } 0 \text { kg ha-1 }\end{array}$} \\
\hline & 155 & \pm & $17^{b}$ & 151 & \pm & $20^{b}$ & 160 & \pm & $18^{b}$ & 98 & \pm & $7^{a}$ \\
\hline$P\left(\mathrm{~kg} \mathrm{ha}^{-1}\right)$ & 20.1 & \pm & $3.7^{\mathrm{bc}}$ & 18.9 & \pm & $2.7^{\mathrm{ab}}$ & 21.4 & \pm & $0.9^{c}$ & 12.8 & \pm & $1.6^{\mathrm{a}}$ \\
\hline $\mathrm{K}\left(\mathrm{kg} \mathrm{ha}^{-1}\right)$ & 6.6 & \pm & $1.1^{\mathrm{bc}}$ & 6.2 & \pm & $1.4^{b}$ & 7.1 & \pm & $0.8^{\mathrm{c}}$ & 4.9 & \pm & $0.2^{\mathrm{a}}$ \\
\hline $\mathrm{Ca}\left(\mathrm{kg} \mathrm{ha} \mathrm{a}^{-1}\right)$ & 18.8 & \pm & $0.9^{b}$ & 15.8 & \pm & $5.4^{\mathrm{ab}}$ & 16.8 & \pm & $1.7^{\mathrm{ab}}$ & 12.5 & \pm & $1.6^{\mathrm{a}}$ \\
\hline $\operatorname{Mg}\left(\mathrm{kg} \mathrm{ha}{ }^{-1}\right)$ & 9.46 & \pm & $0.95^{b c}$ & 8.92 & \pm & $1.28^{b}$ & 9.84 & \pm & $0.78^{c}$ & 8.09 & \pm & $0.10^{\mathrm{a}}$ \\
\hline $\mathrm{Al}\left(\mathrm{kg} \mathrm{ha} \mathrm{a}^{-1}\right)$ & 1.92 & \pm & $0.78^{\mathrm{a}}$ & 1.57 & \pm & $0.93^{a}$ & 1.30 & \pm & $0.44^{\mathrm{a}}$ & 0.88 & \pm & $0.22^{a}$ \\
\hline $\mathrm{B}\left(\mathrm{g} \mathrm{ha}^{-1}\right)$ & 22.8 & \pm & $3.1^{b}$ & 22.2 & \pm & $3.3^{b}$ & 25.2 & \pm & $2.3^{c}$ & 19.5 & \pm & $0.4^{\mathrm{a}}$ \\
\hline $\mathrm{Cu}\left(\mathrm{g} \mathrm{ha}^{-1}\right)$ & 55.0 & \pm & $6.9^{\mathrm{bc}}$ & 52.9 & \pm & $10.0^{b}$ & 56.9 & \pm & $6.3^{c}$ & 33.8 & \pm & $10.0^{\mathrm{a}}$ \\
\hline $\mathrm{Fe}\left(\mathrm{g} \mathrm{ha}^{-1}\right)$ & 1300 & \pm & $525^{a}$ & 1121 & \pm & $629^{a}$ & 893 & \pm & $126^{a}$ & 580 & \pm & $33^{a}$ \\
\hline $\mathrm{Mn}\left(\mathrm{g} \mathrm{ha}^{-1}\right)$ & 205 & \pm & $15^{b}$ & 185 & \pm & $43^{b}$ & 195 & \pm & $22^{b}$ & 131 & \pm & $4^{a}$ \\
\hline Mo $\left(\mathrm{g} \mathrm{ha}^{-1}\right)$ & 12.1 & \pm & $2.1^{b}$ & 9.4 & \pm & $1.3^{\mathrm{ab}}$ & 8.6 & \pm & $2.4^{\mathrm{a}}$ & 7.9 & \pm & $1.1^{\mathrm{a}}$ \\
\hline $\mathrm{Na}\left(\mathrm{g} \mathrm{ha}^{-1}\right)$ & 337 & \pm & $17^{b}$ & 342 & \pm & $118^{b}$ & 370 & \pm & $80^{b}$ & 279 & \pm & $22^{a}$ \\
\hline Zn $\left(\mathrm{g} \mathrm{ha}^{-1}\right)$ & 354 & \pm & $29^{b}$ & 351 & \pm & $44^{b}$ & 389 & \pm & $36^{c}$ & 265 & \pm & $8^{a}$ \\
\hline
\end{tabular}


Table 4d. Effects of BC on nutrient uptake (grain + straw) by sunflower in 2012, cultivated on Chernozem. Values are means \pm S \pm SD; numbers in lines followed by different letters are significantly different at $p<0.05$ (Duncan's multiple range test).

\begin{tabular}{|c|c|c|c|c|c|c|c|c|c|c|c|c|}
\hline \multirow{2}{*}{$\begin{array}{l}\text { Element } \\
\mathrm{N}\left(\mathrm{kg} \mathrm{ha}^{-1}\right)\end{array}$} & \multicolumn{3}{|c|}{$\begin{array}{l}\text { BC } 0 \mathrm{t} \mathrm{ha}^{-1} / \\
\text { N } 75 \mathrm{~kg} \mathrm{ha}^{-1}\end{array}$} & \multicolumn{3}{|c|}{$\begin{array}{l}\text { BC } 24 \mathrm{t} \mathrm{ha}^{-1} / \\
\text { N } 75 \mathrm{~kg} \mathrm{ha}^{-1}\end{array}$} & \multicolumn{3}{|c|}{$\begin{array}{l}\text { BC } 72 \mathrm{tha}^{-1} / \\
\text { N } 75 \mathrm{~kg} \mathrm{ha}^{-1}\end{array}$} & \multicolumn{3}{|c|}{$\begin{array}{l}\text { BC } 72 \text { t ha }^{-1} / \\
\text { N } 0 \text { kg ha }^{-1}\end{array}$} \\
\hline & 140 & \pm & $13^{b}$ & 134 & \pm & $13^{b}$ & 131 & \pm & $11^{b}$ & 98 & \pm & $12^{\mathrm{a}}$ \\
\hline $\mathrm{P}\left(\mathrm{kg} \mathrm{ha}^{-1}\right)$ & 20.7 & \pm & $1.3^{\mathrm{b}}$ & 18.7 & \pm & $2.4^{\mathrm{b}}$ & 21.1 & \pm & $0.8^{\mathrm{b}}$ & 16.0 & \pm & $2.0^{\mathrm{a}}$ \\
\hline $\mathrm{K}\left(\mathrm{kg} \mathrm{ha}^{-1}\right)$ & 127 & \pm & $16^{c}$ & 105 & \pm & $14^{\mathrm{b}}$ & 134 & \pm & $13^{c}$ & 83 & \pm & $14^{\mathrm{a}}$ \\
\hline $\mathrm{Ca}\left(\mathrm{kg} \mathrm{ha}^{-1}\right)$ & 115 & \pm & $8^{\mathrm{a}}$ & 84 & \pm & $31^{\mathrm{a}}$ & 124 & \pm & $36^{\mathrm{a}}$ & 69 & \pm & $16^{\mathrm{a}}$ \\
\hline $\operatorname{Mg}\left(\mathrm{kg} \mathrm{ha}^{-1}\right)$ & 29.8 & \pm & $2.2^{\mathrm{b}}$ & 25.5 & \pm & $1.4^{\mathrm{a}}$ & 25.0 & \pm & $3.3^{\mathrm{ab}}$ & 18.9 & \pm & $3.4^{\mathrm{a}}$ \\
\hline $\mathrm{Al}\left(\mathrm{kg} \mathrm{ha}^{-1}\right)$ & 1.17 & \pm & $0.28^{a}$ & 0.80 & \pm & $0.20^{\mathrm{a}}$ & 1.66 & \pm & $0.70^{\mathrm{a}}$ & 0.79 & \pm & $0.49^{\mathrm{a}}$ \\
\hline $\mathrm{B}\left(\mathrm{g} \mathrm{ha} \mathrm{a}^{-1}\right)$ & 212 & \pm & $23^{b}$ & 172 & \pm & $22^{\mathrm{ab}}$ & 212 & \pm & $28^{b}$ & 150 & \pm & $24^{a}$ \\
\hline $\mathrm{Cu}\left(\mathrm{g} \mathrm{ha}^{-1}\right)$ & 150 & \pm & $15^{b}$ & 123 & \pm & $20^{\mathrm{ab}}$ & 132 & \pm & $13^{\mathrm{ab}}$ & 96 & \pm & $20^{\mathrm{a}}$ \\
\hline $\mathrm{Fe}\left(\mathrm{g} \mathrm{ha} \mathrm{a}^{-1}\right)$ & 1479 & \pm & $1068^{a}$ & 894 & \pm & $491^{a}$ & 1267 & \pm & $536^{a}$ & 1199 & \pm & $1192^{\mathrm{a}}$ \\
\hline $\operatorname{Mn}\left(\mathrm{g} \mathrm{ha}^{-1}\right)$ & 192 & \pm & $20^{\mathrm{ab}}$ & 154 & \pm & $22^{\mathrm{ab}}$ & 200 & \pm & $56^{\mathrm{b}}$ & 113 & \pm & $22^{\mathrm{a}}$ \\
\hline Mo $\left(\mathrm{g} \mathrm{ha}^{-1}\right)$ & 3.84 & \pm & $0.62^{\mathrm{a}}$ & 3.22 & \pm & $0.35^{a}$ & 3.82 & \pm & $0.74^{\mathrm{a}}$ & 5.47 & \pm & $1.37^{\mathrm{b}}$ \\
\hline $\mathrm{Na}\left(\mathrm{g} \mathrm{ha}^{-1}\right)$ & 352 & \pm & $59^{b}$ & 297 & \pm & $69^{b}$ & 250 & \pm & $58^{b}$ & 139 & \pm & $5^{a}$ \\
\hline $\mathrm{Zn}\left(\mathrm{g} \mathrm{ha}^{-1}\right)$ & 337 & \pm & $19^{\mathrm{a}}$ & 328 & \pm & $43^{\mathrm{a}}$ & 362 & \pm & $5^{a}$ & 334 & \pm & $32^{\mathrm{a}}$ \\
\hline
\end{tabular}

A

Spring barley dry mass 2011 (Chernozem, Traismauer)
B

Maize dry mass 2011 (Cambisol, Kaindorf)
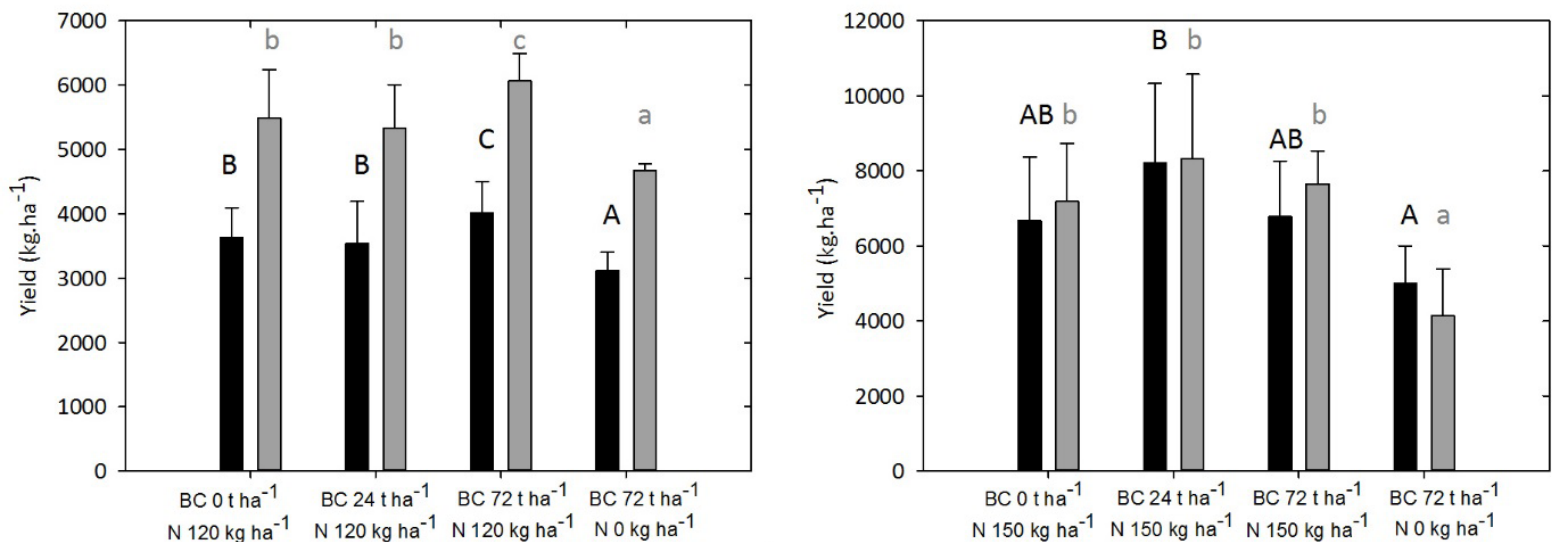

\begin{tabular}{|l} 
straw DM \\
grain DM
\end{tabular}

C Sunflower dry mass 2012 (Chernozem, Traismauer)

Winter wheat dry mass 2012 (Cambisol, Kaindorf)
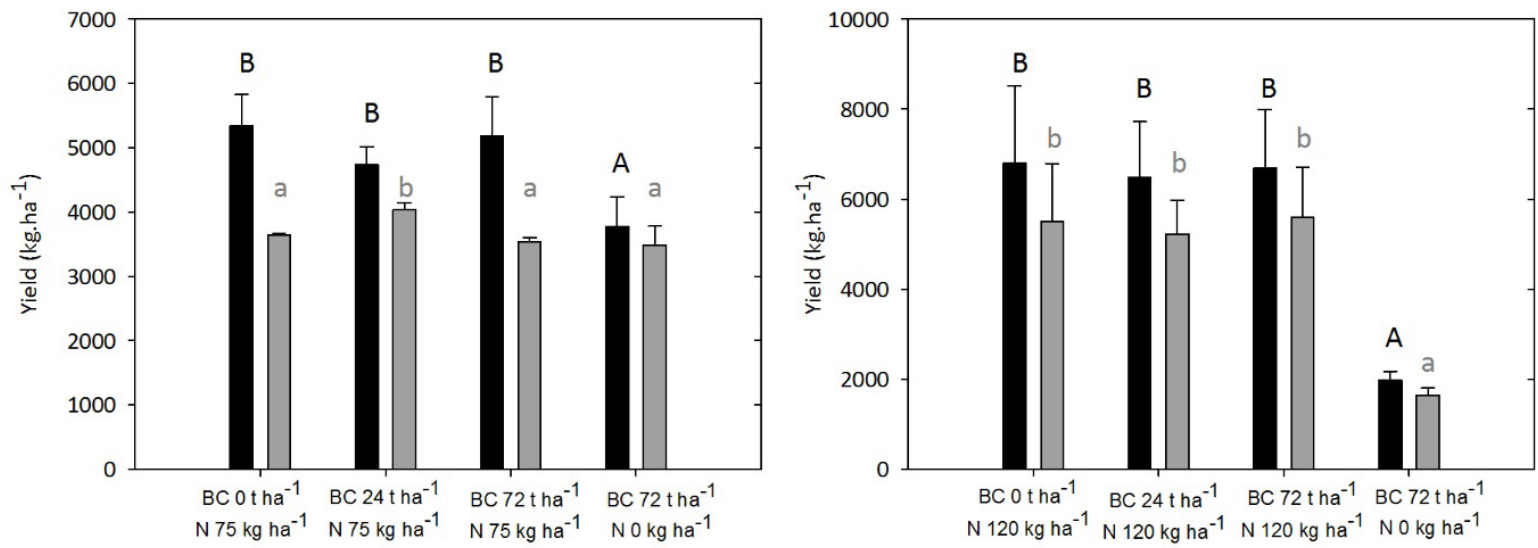

Fig. 3. Grain and straw yield (dry matter (DM) of spring barley (A), maize (B), sunflower (C) and winter wheat (D)) at varying BC and $\mathrm{N}$ application rates. Lower and upper case characters indicate significant differences according to Duncan's multiple range test $(p<0.05)$ for grain and straw yield, respectively. 


\section{Discussion}

Soil

In accordance with Karhu et al. (2011), Kammann et al. (2011) and Downie et al. (2011) our plots with BC amendment had higher WHC than plots without BC treatment. In comparison to Karhu et al. (2011), who found a WHC increase of $11 \%$ after BC amendment, the WHC of our BC-amended Cambisol was $21 \%$ higher than without BC application (see Table 2), probably because of the high application rate in our experiment. The changes in the Chernozem were in a similar range but not statistically significant. Kammann et al. (2011) found an increased drought tolerance after BC application in a greenhouse study, and Karhu et al. (2011) reported that due to the high amount of small pores in $\mathrm{BC}$ the soil water retention capacity was improved.

The positive effects on soil water retention in our study (pF curve; Fig. 2) were also consistent with studies from Liu et al. (2012) and Petter et al. (2012). The latter investigated the effects of eucalyptus BC in a field experiment on a course textured Dystric Plinthosol in Brazil. Liu et al. (2012) found in their field experiment that BC addition together with compost doubled the plant available WHC. Similarly, Cornelissen et al. (2013) observed increased PAW in their field experiment in West Zambia. In that study, the highest PAW was measured after using 5\% maize $B C$ in a Haplic Luvisols with silty clay. BC plots on our Chernozem were able to store approx. $10 \mathrm{~mm}$ more water in the upper $17 \mathrm{~cm}$ (depth of BC incorporation after 2 years) in comparison to plots without BC treatment. In the Cambisol, PAW was significantly higher (3.1 vol.-\% increase) in the plots with the highest BC treatment ( 72 t ha $^{-1}+$ $\mathrm{N}$ supply) than in the plots without BC application (Fig. 2). Jeffery et al. (2011) suggested in a meta-analysis that WHC was one of the reasons for crop yield increase and nutrient availability after BC application. The most positive effects in their meta-analysis were cited from a study applying $100 \mathrm{t} \mathrm{ha}^{-1} \mathrm{BC}$. Similarly, the highest WHC in our study was also found after the highest $\mathrm{BC}$ application rate, $72 \mathrm{t} \mathrm{ha}^{-1}$. Downie et al. (2011) claimed that improved soil WHC may strengthen the case of BC as a climate change adaptation tool. Indeed, temperate climate regions, which are adversely impacted by water stress conditions, could profit from enhanced water retention effectuated by BC application.

According to Verheijen et al. (2010), most BCs cause an increase in soil pH when the initial pH in a soil is low. The positive effects of $\mathrm{BC}$ on plant productivity and improved crop growth may be due to a liming effect with consequences for the cycling of $C$ and nutrients (Verheijen et al. 2010, Rajkovich et al. 2012, Powlson et al. 2011, Jeffery et al. 2011). In our study, with soils of neutral pH, a notable pH increase after BC application occurred only in the Cambisol and only in the first year, whereas the higher original $\mathrm{pH}$ in the Chernozem was hardly affected.

BC application generally increased CAL-extractable $\mathrm{P}$ and $\mathrm{K}$ in the first year, while these effects diminished in the second year at both sites. Fresh BCs may contain significant amounts of soluble P and K (Kloss et al. 2012), which contribute to the plant-available pool upon incorporation in the soil, but may rapidly be removed from this pool by immobilisation, plant uptake or leaching. The NSP of the studied soils was hardly affected by BC application, and thus, indicated no impairment of $\mathrm{N}$ mineralisation; only in the first year, the NSP was significantly lower after $72 \mathrm{t} \mathrm{ha}^{-1} \mathrm{BC}$ treatment without additional $\mathrm{N}$ supplement in the Chernozem, compared to the same $\mathrm{BC}$ treatment but with additional $\mathrm{N}$ application. The impacts of $\mathrm{BC}$ addition on processes of the soil $\mathrm{N}$ cycle are frequently discussed controversially. Due to the high $\mathrm{C} / \mathrm{N}$ ratio of $\mathrm{BCs}, \mathrm{N}$ immobilisation in $\mathrm{BC}$ treated plots might be expected. An increase of soil $\mathrm{N}$ immobilisation after BC addition was indeed observed by Bruun et al. (2012), Zheng et al (2013b), Tammeorg et al. (2013) and Lehmann et al. (2003). However, the recalcitrant C in BC may restrict N immobilisation (Chan and Xu 2009). Bruun et al. (2012) documented in their incubation study a large influence of the $\mathrm{BC}$ pyrolysis method on the immobilisation of $\mathrm{N}$. While $\mathrm{BC}$ produced with fast pyrolysis and low temperature may still contain bio-available $C$ for the microbial population, a slow pyrolysis BC-product, as in our study, might be completely pyrolised and contain less volatile / bio-available C. Furthermore, Rajkovich et al. (2012) concluded from their greenhouse pot trial that a high pyrolysis temperature of $500-600^{\circ} \mathrm{C}$ might minimise $\mathrm{N}$-immobilisation. Along these lines, Novak et al. (2010) found stimulated N mineralisation after BC amendment to a forest soil in their laboratory incubation study. Clough et al. (2013) pointed at the urgency of long-term studies on N immobilisation. Most studies are short-term and $\mathrm{N}$ immobilisation might occur because of labile $\mathrm{C}$ addition in the $\mathrm{BC}$. The above discussion shows that application of $\mathrm{BC}$ may result in varying effects on $\mathrm{N}$ immobilisation / mineralisation, ranging from decreased to increased mineralisation or showing no effect; the latter was observed in our study.

BC application significantly decreased bulk density in both soil types as was also observed by Abel et al. (2013) and Herath et al. (2013). Bulk density may decrease because BC itself has a much lower bulk density and higher porosity than mineral particles. Laird et al. (2010), Sohi et al. (2009), Verheijen et al. (2010) and Zhang et al. (2012) 
reported positive effects of lowered bulk density (and higher organic matter content) due to BC application to the soil. These positive effects include increased nutrient cycling, retention of PAW, reduced soil compaction, increased soil aeration and increased crop yield.

\section{Crop yield}

In our study, BC treated plots (with identical N supply) showed crop yields similar to the mineral N fertilised plots. Although our experimental BC application rates were much higher than usually recommended ones, we could show that no adverse impacts on yield performance appeared, sufficient $\mathrm{N}$ supply provided. However, distinct yield decreases were observed, especially for maize and winter wheat on the Cambisol, when BC was applied without $\mathrm{N}$ supplement (Fig. 3). This emphasises the well-known effect of $\mathrm{N}$ availability, being the most limiting factor for crop yield. Although more $\mathrm{N}$ was contained in the $\mathrm{BC}$ additive than in the mineral fertiliser, the crops could not take advantage of this $\mathrm{BC}$ pool, at least not in the short term. The positive effects of improved WHC were reflected by a barley yield increase of $10 \%$ (Fig. $3 \mathrm{~A}$ ) in the first experimental year on the Chernozem site (Traismauer), where a severe precipitation deficit was recorded (Fig. 1).

\section{Nutrient uptake}

Contrary to our study, Uzoma et al. (2011) found a significant increase in nutrient uptake after BC amendment to the soil; this may have been caused by the usage of cow manure as feedstock. The authors assumed that moderate amounts of $\mathrm{BC}$ application (15 and $20 \mathrm{t} \mathrm{ha}^{-1}$ ) may have positive effects on the soil and the resulting increased nutrient uptake may occur due to a great availability of nutrients from the soil. On the contrary, Rajkovich et al. (2012) found the highest N uptake after a low BC addition (0.2\%) if BC was produced at low pyrolysis temperatures $\left(300^{\circ} \mathrm{C}\right)$; at addition rates of $2 \%$ or higher, the $\mathrm{Na}$ content of the $\mathrm{BC}$ reduced the growth of corn in their pot experiment. In our study, $72 \mathrm{t} \mathrm{ha}^{-1} \mathrm{BC}$ without additional $\mathrm{N}$ fertiliser led to a significantly lower $\mathrm{N}$ uptake, mainly due to significant yield depressions. When additional $\mathrm{N}$ was supplied with $\mathrm{BC}$, the uptake of $\mathrm{P}, \mathrm{K}$ and micronutrients was not significantly enhanced by BC addition for the different crops (Table $4 a-4 d$ ). The reason for this may be the use of wood-based $B C$ in our experiment that releases nutrients more slowly than straw-based BC (Kloss et al. 2013). However, the study of Petter et al. (2012), who also used wood-based BC (eucalyptus), showed positive effects of $\mathrm{BC}$ on the availability of $\mathrm{P}$ and $\mathrm{Ca}$ in a sandy soil, which may have been due to the low nutrient status of their experimental soil, the sandy texture and the relatively low soil pH of 5.6. In contrast to the increased nutrient uptake by maize that was observed by Major et al. (2010) after BC amendment on an acidic Haplustox $(\mathrm{pH}$ 3.9), our results of nutrient uptake from a neutral soil were less clear-cut. Alburquerque et al. (2013) found increased $\mathrm{P}, \mathrm{Mg}$ and $\mathrm{Zn}$ uptakes and decreased $\mathrm{K}, \mathrm{Ca}$ and $\mathrm{Mg}$ after different BC addition to a nutrient-poor, slightly acidic soil and stressed the importance of the synergistic effects of mineral fertiliser application together with BC. Similarly, P uptake in our study was slightly increased, except for maize, and K uptake was decreased, except for wheat, when $\mathrm{BC}$ was added with additional $\mathrm{N}$ compared to $\mathrm{BC}$ without $\mathrm{N}$ supplement.

\section{Conclusions}

Our results show that in temperate regions $B C$ application may show positive effects when drought conditions impair plant growth. In a year with exceptionally low precipitation, increased WHC and PAW through BC addition might have been the reason for the observed yield increase. The decrease of soil bulk density, still observable after 2 years of field experiments, shows that application of BC can positively influence soil structure; consequently, $\mathrm{BC}$ can be considered as a soil amendment to increase water infiltration and to decrease the vulnerability of soils to compaction and erosion.

Nutrients from wood-based BC made a minimal contribution to the macro- and micronutrient supply of the experimental crops. Moreover, there was a negative trend in yield and nutrient uptake when $\mathrm{N}$ was not supplemented, indicating that even high total $\mathrm{N}$ pools in wood-based $\mathrm{BC}$ are released too slowly to contribute significantly to plant nutrition.

Our results show that the benefits of wood-based BC application to neutral, fertile soils in a temperate climate were restricted to the soil physical effects of increased WHC / PAW and lower BD. An effective provision of nutrients from $B C$ to crops would require the use of alternative feedstocks for pyrolysis or supplementary addition of mineral or organic fertilisers. If the main objective of adding BC is carbon sequestration in soil, even at application rates as high as $72 \mathrm{t} \mathrm{ha}^{-1}$, adverse crop growth and yield effects do not have to be suspected, sufficient nutrient supply from other sources provided. 


\section{Acknowledgements}

The authors gratefully acknowledge the financial support from the Austrian "Klima- und Energiefonds" and the Austrian Research Promotion Agency (FFG, project nr. 825438, third call “Neue Energien 2020"). Technical support by Christian Mayer, Patrick Kobe and Walter Frank was highly valued. We are grateful to the landowners Rudolf Hofmann and Johann König for permitting the experimental installation on their fields.

\section{References}

Abel, S., Peters, A., Trinks, S. Schonsky, H., Facklam, M. \& Wessolek, G. 2013. Impact of biochar and hydrochar addition on water retention and water repellency of sandy soil. Geoderma 202: 183-191.

Alburquerque, J.A., Salazar, P., Barrón, V., Torrent, J., del Carmen del Campillo, M., Gallardo, A. \& Villar, R. 2013. Enhanced wheat yield by biochar addition under different mineral fertilization levels. Agronomy for Sustainable Development 33: 475-484.

Asai, H., Samson, B.K., Stephan, H.M., Songyikhangsuthor, K., Homma, K., Kiyono, Y., Inoue, Y., Shiraiwa, T. \& Horie, T. 2009. Biochar amendment techniques for upland rice production in Northern Laos 1. Soil physical properties, leaf SPAD and grain yield. Field Crops Research 111: 81-84.

Atkinson, C.J., Fitzgerald, J.D. \& Hipps, N.A. 2010. Potential mechanisms for achieving agricultural benefits from biochar application to temperate soils: a review. Plant Soil 337: 1-18.

Blake, G.R. \& Hartge, K.H. 1986. Bulk density. In: Klute, A (ed.). Methods of soil analysis, Part 1, Physical and mineralogical methods. Agronomy Monograph 9, $2^{\text {nd }}$ edn. Madison, Wisconsin, USA: American Society of Agronomy, Soil Science of America. p. 363-375.

Blackwell, P., Riethmuller, G., \& Collins, M. 2009. Biochar application to soil. In: Lehmann, J. \& Joseph, S. Biochar for Environmental Management: Science and Technology. London, UK: Earthscan. p. 207-226.

Bruun, E.W., Ambus, P., Egsgaard, H. \& Hauggaard-Nielsen, H. 2012. Effects of slow and fast pyrolysis biochar on soil C and $\mathrm{N}$ turnover dynamics. Soil Biology \& Biochemistry 46: 73-79.

Burt, R. (ed.). 2004. Soil survey laboratory methods manual. Soil survey investigations report 42. Washington, DC, USA: USDA-NRCS. 530 p.

Chan, K.Y. \& Xu, Z. 2009. Biochar: nutrient properties and their enhancement. In: Lehmann, J. \& Joseph, S. (eds.). Biochar for Environmental Management: Science and Technology. London, UK: Earthscan. p. 67-84.

Clough, T.J., Condron, L.M., Kamman, C. \& Müller, C. 2013. A review of biochar and soil nitrogen dynamics. Agronomy 3: 275-293.

Cornelissen, G., Martinsen, V., Shitumbanuma, V., Alling, V., Breedveld, G.D., Rutherford, D.W., Sparrevik, M., Hale, S.E., Obia, A. \& Mulder, J. 2013. Biochar effect on maize yield and soil characteristics in five conservation farming sites in Zambia. Agronomy 3: $256-274$.

da Costa, M.L., Kern, D.C., Pinto, A.H.E. \& Souza, J.R.T. 2004. The ceramic artifacts in archaeological black earth (terra preta) from lower Amazon region, Brazil: mineralogy. Acta Amazonia 34: 165-178.

Dixon, W.J. 1950. Analysis of extreme values. The Annals of Mathematical Statistics 21: 488-506.

Downie, E.A., Van Zwieten, L., Smernik, R.J., Morris, S., \& Munroe, P.R. 2011. Terra preta australis: Reassessing the carbon storage capacity of temperate soils. Agriculture, Ecosystems and Environment 140: 137-147.

Gaskin, J., Speir, R., Harris, K., Das, K., Dewey Lee, R., Morris, L. \& Fisher, D.S. 2010. Effect of peanut hull and pine chip biochar on soil nutrients, corn nutrient status, and yield. Agronomy Journal 102: 623-633.

Gaskin, J., Steiner, C., Harris, K., Das, K., \& Bibens, B. 2008. Effect of low-temperature pyrolysis conditions on biochar for agricultural use. Transactions of the American Society of Agricultural and Biological Engineers 51: 2061-2069.

Glaser, B., Lehmann, J., \& Zech, W. 2002. Ameliorating physical and chemical properties of highly weathered soils in the tropics with charcoal - a review. Biology and Fertility of Soils 35: 219-230.

Goldberg, E. 1985. Black carbon in the environment. New York: Wiley. 198 p.

Güereña, D., Lehmann, J., Hanley, K., Enders, A., Hyland, C. \& Riha, S. 2013. Nitrogen dynamics following field application of biochar in a temperate North American maize-based production system. Plant and Soil 365: 239-254.

Herath, H.M.S.K., Camps-Arbestain, M. \& Hedley, M. 2013. Effect of biochar on soil physical properties in two contrasting soils: An Alfisol and an Andisol. Geoderma 209: 188-197.

Ippolito, J.A., Laird, D.A. \& Busscher, W.J. 2012. Environmental benefits of biochar. Journal of Environmental Quality 41: 967-972.

Jeffery, S., Verheijen, F.G.A., van der Velde, M., A.C. \& Bastos, A.C. 2011. A quantitative review of the effects of biochar application to soils on crop productivity using meta-analysis. Agriculture, Ecosystems and Environment 144: 175-187.

Jones, D.L., Rousk, J, Edwards-Jones, G., deLuca, T.H. \& Murphy, D.V. 2012. Biochar-mediated changes in soil quality and plant growth in a three year field trial. Soil Biology \& Biochemistry 45: 113-124.

Kammann, C.I., Linsel, S., Gößling, J.W. \& Koyro, H.-W. 2011. Influence of biochar on drought tolerance of Chenopodium quinoa Willd and on soil-plant relations. Plant and Soil 345: 195-210.

Karhu, K., Mattila, T., Bergström, I. \& Regina K. 2011. Biochar addition to agricultural soil increased $\mathrm{CH}_{4}$ uptake and water-holding capacity - Results from a short-term pilot field study. Agriculture, Ecosystems and Environment 140: 309-313.

Kloss, S., Zehetner, F., Dellantonio, A., Hamid, R., Ottner, F., Liedtke, V., Schwanninger, M., Gerzabek, M.H. \& Soja, G. 2012. Characterization of slow pyrolysis biochars: Effects of feedstocks and pyrolysis temperature on biochar properties. Journal of Environmental Quality 41: 990-1000. 
Kloss, S., Zehetner, F., Wimmer, B., Buecker, J., Rempt, F. \& Soja, G. 2013. Biochar application to temperate soils: Effects on soil fertility and crop growth under greenhouse conditions. Journal of Plant Nutrition and Soil Science. DOI: 10.1002/jpln.201200282.

Klute A. 1986. Water retention: Laboratory methods. In: Klute, A (ed.). Methods of soil analysis, Part 1, Physical and mineralogical methods. Agronomy Monograph 9, $2^{\text {nd }}$ edn. Madison, Wisconsin, USA: American Society of Agronomy, Soil Science of America. p. 363-375

Kuhlbusch, T. \& Crutzen, P. 1995. Toward a global estimate of black carbon in residues of vegetation fires representing a sink of atmospheric $\mathrm{CO}_{2}$ and a source of $\mathrm{O}_{2}$. Global Biogeochemical Cycles 9: 491-501.

Kuka, K., Franko, U., Hanke, K. \& Finkenbein, P. 2013. Investigation of different amendments for dump reclamation in Northern Vietnam. Journal of Geochemical Exploration 132: 41-53.

Laird, D.A., Fleming, P., Davis, D.D., Horton, R., Wang, B. \& Karlen, D.L. 2010. Impact of biochar amendments on the quality of a typical Midwestern agricultural soil. Geoderma 158: 443-449.

Lehmann, J., Kern, D.C., German, L.A., McCann, J., Martins, G.C. \& Moreira, A. 2003. Soil fertility and production potential. In: Lehmann, J., Kern, D.C., Glaser, B., \& Woods, W. (eds.). Amazonian dark earths: Origin, properties, management. Dordrecht, The Netherlands: Kluwer Academic Publishers. p. 105-124.

Lehmann, J. 2007. Bio-energy in the black. Frontiers in Ecology and the Environment 5: 381-387.

Liu, J., Schulz, H., Brandl, S., Miehtke, H., Huwe, B. \& Glaser, B. 2012. Short-term effect of biochar and compost on soil fertility and water status of a dystric cambisol in NE Germany under field conditions. Journal of Plant Nutrition and Soil Science 175: 698-707.

Major, J., Rondon, M., Molina, D., Riha, S.J. \& Lehmann, J. 2010. Maize yield and nutrition during 4 years after biochar application to a Colombian savanna Oxisol. Plant Soil 333: 117-128.

Murphy, J. \& Riley, J. P. 1962. A modified single solution method for the determination of phosphate in natural waters. Analytica Chimica Acta 27: 31-36.

Novak, J.M., Busscher, W.J., Watts, D.W., Laird, D.A., Ahmedna, M.A. \& Niandou, M.A.S. 2010. Short-term CO 2 mineralization after additions of biochar and switchgrass to a typic Kandiudult. Geoderma 154: 281-288.

Novotny, E.H., Hayes, M.H.B, Madari B.E., Bonagamba, T.J., deAzevedo E.R., de Souza A.A., Song, G., Nogueira C.M., \& Mangrich, A.S. 2009. Lessons from terra preta de indios of the Amazon region for the utilisation of charcoal for soil amendment. Journal of the Brazilian Chemical Society 20: 1003-1010.

Petter, F.A., Madari, B. E., Silva, M.A.S. da, Carneiro, M.A.C., Carvalho, M.T. de M., Marimon junior, B.H. \& Pacheco, L.P. 2012. Soil fertility and upland rice yield after biochar application in the Cerrado. Pesquisa Agropecuária Brasileira 47: 699-706.

Powlson, D.S., Whitmore, A.P. \& Goulding, K.W.T. 2011. Soil carbon sequestration to mitigate climate change: A critical re-examination to identify the true and the false. European Journal of Soil Science 62: 42-55.

Pramod, Jha., Biswas, A.K., Lakaria, B.L. \& Subba Rao, A. 2010. Biochar in agriculture - Prospects and related implications. Current science 99: 1218-1225.

Quilliam, R.S., Marsden, K.A., Gertler, C., Rousk, J., DeLuca, T.H. \& Jones, D.L. 2012. Nutrient dynamics, microbial growth and weed emergence in biochar amended soil are influenced by time since application and reapplication rate. Agriculture, Ecosystems and Environment 158: 192-199.

Rajkovich, S., Enders, A., Hanley, K., Hyland, C., Zimmermann, A.R. \& Lehmann, J. 2012. Corn growth and nitrogen nutrition after additions of biochars with varying properties to a temperate soil. Biology and Fertility of Soils 48: 271-284.

Singh, B., Singh, B.P., \& Cowie, A. 2010. Characterisation and evaluation of biochars for their application as soil amendment. Austrian Journal of Soil Research 48: 516-525.

Sohi, S., Krull, E., Lopez-Capel, E., \& Bol, R. 2010. A review of biochar and its use and function in soil. Advances in Agronomy 105: 47-82.

Sohi, S., Lopez-Cabel, E., Krull, E. \& Bol, R. 2009. Biochar, climate change and soil: A review to guide future research. CSIRO Land and Water Science Report 05: 1834-6618.

Tabatabai, M.A. \& Bremner, J.M. 1991. Automated instruments for determination of total carbon, nitrogen, and sulfur in soils by combustion techniques. In: Smith, K.A. (ed.). Soil Analysis. New York: Marcel Dekker. p. 261-286.

Tammeorg, P., Simojoki, A., Mäkelä, P., Stoddard, F.L., Alakukku, L. \& Helenius, J. 2013. Biochar application to a fertile sandy clay loam in boreal conditions: Effects on soil properties and yield formation of wheat, turnip rape and faba bean. Plant and Soil. DOI 10.1007/s11104-013-1851-5.

Uzoma, K.C., Inoue, M., Andry, H., Fijimaki, H., Zahoor, A. \& Nishihara, E. 2011. Effect of cow manure biochar on maize productivity under sandy soil condition. Soil Use and Management 27: 205-212.

Verheijen, F.G.A., Jeffery, S., Bastos, A.C., van der Velde, M., \& Diafas, I. 2010. Biochar application to soils - A critical scientific review of effects on soil properties, processes and functions. Luxembourg, LU: Office for the Official Publications of the European Communities. $149 \mathrm{p}$.

Yang, Z.-B., Rao, I.M. \& Horst, W.J. 2013. Interaction of aluminium and drought stress on root growth and crop yield on acid soils. Plant and Soil 372: 3-25.

Zhang, A., Liu, Y., Pan, G., Hussain, Q., Li, L., Zheng, J. \& Zhang, X. 2012. Effect of biochar amendment on maize yield and greenhouse gas emissions from a soil organic carbon poor calcareous loamy soil from Central China plain. Plant and Soil 351: $263-275$.

Zheng, H., Wang, Z., Deng, X., Zhao, J., Luo, Y., Novak, J., Herbert, S. \& Xing, B. 2013a. Characteristics and nutrient values of biochars produced from giant reed at different temperatures. Bioresource Technology 130: 463-471.

Zheng, H., Wang, Z., Deng, X., Herbert, S. \& Xing, B.S. 2013b. Impacts of adding biochar on nitrogen retention and bioavailability in agricultural soil. Geoderma 206: 32-39. 